\title{
Clonal Variants of Differentiated P19 Embryonal Carcinoma Cells Exhibit Epidermal Growth Factor Receptor Kinase Activity
}

\author{
C. L. Mummery, ${ }^{1}$ A. Feijen, P. T. van der SaAG, C. E. van den Brink, and S. W. de LaAt \\ Hubrecht Laboratory, International Embryological Institute, Uppsalalaan 8, 3584 CT Utrecht, The Netherlands \\ Received September 24, 1984; accepted in revised form December 7, 1984
}

\begin{abstract}
Differentiated clonal cell lines were isolated from pluripotent P19 embryonal carcinoma (EC) cells treated as aggregates with retinoic acid. Two were characterized in detail. The lines differ in morphology, proliferation rate, the production of plasminogen activator, and in their mitogenic response to insulin but both produce extracellular matrix proteins and can be serially passaged over extended periods, in contrast to differentiated derivatives of many other EC lines. Further, both lines have receptors for and respond mitogenically to epidermal growth factor (EGF). Endogenous phosphorylation of several proteins, including the EGF receptor $(150 \mathrm{kDa})$ and a $38-\mathrm{kDa}$ protein, is induced by EGF in membranes isolated from these cells. Preincubation of membranes with FGF renders them able to catalyze phosphorylation of tyrosine residues in exogenously added peptide substrates. High voltage electrophoresis confirmed the tyrosine specificity of the phosphorylation on the 150- and 38-kDa bands. By contrast, similar experiments in undifferentiated cells showed that intact $\mathrm{P} 19 \mathrm{EC}$ neither bind nor respond to EGF mitogenically and EGF induces no changes in phosphorylation in isolated membranes. 1985 Academic Press, Inc.
\end{abstract}

\section{INTRODUCTION}

Mouse embryonal carcinoma (EC) cells, the undifferentiated stem cells of teratocarcinomas, are used as a model system to study early events involved in embryonic differentiation and development because of the many properties they have in common with pluripotent embryonic cells (Graham, 1977; Martin, 1980). During exponential growth, EC cells show little tendency to differentiate but may be induced to do so by changes in local cell density (aggregation or embryoid body formation) and/or addition of various chemical stimuli, such as retinoic acid (RA) and dimethylsulfoxide (DMSO) (Artzt et al., 1973; Martin and Evans, 1975; Strickland and Mahdavi, 1978; Jetten et al., 1979). Differentiation is frequently accompanied by an ordered decrease in growth rate (Mummery et al., 1984) and the development of mitogenic responsiveness to externally added growth factors such as EGF (Rees $e l$ al., 1979). In the developing mouse embryo it is still unclear when functional EGF receptor expression first appears and how it is regulated (Hortsch et al., 1984). Use of appropriate EC cell lines may provide a straightforward means of addressing these problems in particular. Determination of many of the biochemical parameters associated with regulation of the EGF receptor, often require large numbers of cells. Such determinations would, therefore, be greatly facilitated by the availability of pure populations of cells in different states of differentiation. The isolation of

\footnotetext{
${ }^{1}$ To whom reprint requests should be addressed.
}

teratocarcinoma-derived, differentiated cell lines has, however, proved difficult because of low cloning efficiency, but a number of successes have been reported (Lehman et al., 1974; Rheinwald et al., 1975; Nicolas, 1976; Morgan et al., 1983). Here, we report the isolation of two such differentiated clonal lines from a pluripotent EC cell line, P19 (McBurney et al., 1982a,b; JonesVilleneuve et al., 1982) aggregated in the presence of RA. These lines differ strikingly in morphology, in the expression of various biochemical markers, and in their response to growth factors. In contrast to many differentiated derivatives of other EC lines, those of P19 can be serially passaged and remain phenotypically stable over extended periods. Both lines respond mitogenically to EGF, in contrast to undifferentiated stem cells, whereas only one of the clones responds as, for example, differentiated PC13 cells (Heath et al., 1981) to nanogram per milliliter concentrations of insulin. We have isolated plasma membranes from these cells and report for the first time endogenous phosphorylation of the EGF receptor $(150 \mathrm{kDa})$ and a $38-\mathrm{kDa}$ protein by EGF on tyrosine residues in the differentiated progeny of an EC line. Further we show that after preincubation with EGF these membranes are able to catalyze phosphorylation of tyrosine residues in exogenous peptide substrates.

\section{MATERIALS AND METHODS}

\section{Cell Culture and Isolation of Differentiated Clones}

P19 EC cells were cultured as described previously for other EC lines (Mummery et al., 1984) on gelatinized 
flasks in a 1:1 mixture of Dulbecco's minimum essential medium (DMEM) and Ham's F12 medium (DF) containing $7.5 \%$ fetal calf serum (Flow Laboratories) and buffered with $\mathrm{NaHCO}_{3}(44 \mathrm{mM})$ in a $5 \% \mathrm{CO}_{2}$ atmosphere. Cells were subcultured in $0.125 \%(\mathrm{w} / \mathrm{v})$ trypsin, $50 \mathrm{~m} M$ ethylene diamine tetraacetic acid (EDTA) in $\mathrm{Ca}^{2+}, \mathrm{Mg}^{2+}$-free phosphate-buffered saline (PBS). For differentiation, cells were aggregated (by plating 2 $\times 10^{5}$ cells $/ 2 \mathrm{ml}$ in bacteriological petri dishes) in the presence of all-trans-RA $\left(5 \times 10^{-7} M\right)$ for 3 days then replated in tissue-culture grade plastic dishes (McBurney et al., 1982b). Four days later, neurites were visible in about $70 \%$ of aggregates. After 2 weeks, cultures consisted of a heterogeneous mixture of cell types; suspensions of these cells were diluted to a density of 1 cell $/ \mathrm{ml}$ then plated in 96 -well plate (Costar; $200 \mu \mathrm{l} /$ well). Three weeks later, 13 wells contained colonies which were subcultured to increasingly larger culture flasks. After growth to confluence cells were routinely cultured using a split ratio 1:5.

\section{Characterization of Clones}

(i) Plasminogen activator ( $P A$ ) production. Cells were grown in confluence in $3.5-\mathrm{cm}$ diameter petri dishes (Costar); $800 \mu \mathrm{l}$ of growth medium was conditioned by these cultures for $24 \mathrm{hr}$ before cells were counted. PA levels were determined in $50-\mu$ l samples of the conditioned medium as described by Unkeless et al. (1973), using an incubation time of $2 \mathrm{hr}$ and human urokinase (Leo Pharmaceuticals) as standard. Data was expressed as Plough units PA produced per $10^{6}$ cells per $24 \mathrm{hr}$.

(ii) Immunofluorescence. Cells grown on gelatine coated, glass coverslips were fixed with $3 \%$ formaldehyde for $20 \mathrm{~min}$, quenched with $50 \mathrm{mM} \mathrm{NH} \mathrm{NH}_{4} \mathrm{Cl}$ for 10 min, incubated with antibody then the appropriate FITC-labeled conjugate for $30 \mathrm{~min}$ at $37^{\circ} \mathrm{C}$. Antibodies used were as follows: rabbit anti-human fibronectin (from S. K. Brahma, University of Utrecht), rabbit anti-mouse laminin (BRL, Cambridge, UK), monoclonal anti-SSEA 1 (from P. Stern, Oxford), and sheep antigoat $\alpha$-fetoprotein (AFP; from K. Hagenaars, NIH, Utrecht). For AFP determination, cells were fixed with 99\% ethanol, $1 \%$ glacial acetic acid.

(iii) Alkaline phosphatase. Cells were lysed by freezing/thawing and alkaline phosphatase was measured as described by Berstine et al. (1973).

(iv) Soft agar growth. The percentage of cells able to form colonies in soft agar was determined by plating $1 \times 10^{1}$ cells $/ 6$-cm diameter petri dish as described by Todaro et al. (1981).

\section{${ }^{3} H-T d R$ Incorporation}

Cells were plated at $5 \times 10^{4}$ cells per $1 \mathrm{~cm} \phi$ well in DF $+7.5 \%$ FCS. After $24 \mathrm{hr}$, medium was replaced by
$\mathrm{DF}+0.5 \%$ FCS. EGF (receptor grade; Collaborative Research), insulin (bovine; Sigma), or $10 \%$ FCS were added $72 \mathrm{hr}$ later without change of medium. After 8 $\mathrm{hr},\left[{ }^{3} \mathrm{H}\right] \mathrm{TdR}(0.5 \mu \mathrm{Ci} / \mathrm{ml}, 55 \mathrm{Ci} / \mathrm{mmole})$ was added and cells were incubated a further $16 \mathrm{hr}$ at $37^{\circ} \mathrm{C}$. Radioactivity incorporated into TCA-precipitable material was determined by liquid scintillation counting.

\section{${ }^{125}$ I-EGF Binding}

(i) Cells in monolayer. Cells $\left(0.5 \times 10^{6}\right)$ were plated in 3.5-cm gelatinized dishes (Costar) and grown for 24 $\mathrm{hr}$ before use. The binding assay buffer contained DMEM, Hepes (25 $\mathrm{nM}$ ), and $0.1 \%(\mathrm{w} / \mathrm{v})$ bovine serum albumin (BSA), as previously described (Mummery et al., 1983). Cell monolayers were incubated with ${ }^{125} \mathrm{I}$ EGF $\left(1.67 \times 10^{-10} M ; 250,000 \mathrm{cpm}\right.$; NEN $)$ and varying amounts of unlabeled EGF (from zero to $2 \times 10^{-8} \mathrm{M}$ ) in $1 \mathrm{ml}$ buffer for $2 \mathrm{hr}$ at room temperature (ca. $20^{\circ} \mathrm{C}$ ), unless indicated otherwise. The mixture was aspirated and dishes were washed five times with ice-cold phosphate-buffered saline. Cells were removed with $0.5 \mathrm{M}$ $\mathrm{NaOH}$ and counted in a gamma counter. The data points shown are the mean of values in 3 -fold. Similar results were obtained in three separate determinations. Nonspecific binding was determined by measuring the bound counts in the presence of a large excess (200fold over ${ }^{125}$ I-EGF) of unlabeled EGF and was less than $10 \%$ of the specifically bound counts.

(ii) Isolated membranes. Membranes isolated according to Thom et al. (1977) from differentiated clones and EC cells ( $100 \mu \mathrm{g}$ protein per sample) were incubated with ${ }^{125} \mathrm{I}$-EGF $\left(6.68 \times 10^{-9} \mathrm{M} ; 1 \times 10^{6} \mathrm{cpm}\right)$ for $90 \mathrm{~min}$ at $18^{\circ} \mathrm{C}$, in a volume made up to $100 \mu 1$ with $10 \mathrm{mM}$ Hepes $(\mathrm{pH} 7.4)$ containing $1 \%(\mathrm{w} / \mathrm{v})$ bovine serum albumin. As required, excess unlabeled EGF was added to a concentration of $5 \mu \mathrm{g} / \mathrm{ml}$. Labeled EGF then bound was crosslinked to its receptor by incubating with disuccininimidyl suberate (DSIS; $0.5-1.0 \mathrm{mM}$; Pilch and Czech, 1979) for $15 \mathrm{~min}$ at $18^{\circ} \mathrm{C}$; the crosslinker was quenched with $900 \mu 10.01 \mathrm{~m}$ Tris-HCl/1 $\mathrm{m} M$ EDTA (pH 7.4), the sample centrifuged for $45 \mathrm{~min}$ at $100,000 \mathrm{~g}$, resuspended in SDS-sample buffer, and incubated for $3 \mathrm{~min}$ at $100^{\circ} \mathrm{C}$. Samples were then subjected to SISgel electrophoresis (7.5-15\% polyacrylamide gel) and autoradiography.

\section{Phosphorylation Assays}

(i) Endogenous phosphorylation of membrane proteins. Membranes (50 $\mu \mathrm{g} / \mathrm{sample})$ isolated from differentiated clones and EC cells as above, were preincubated with various concentrations of EGF for $10 \mathrm{~min}$ at $0^{\circ} \mathrm{C}$. The phosphorylation reaction was started by adding membranes to a mixture containing Hepes ( $20 \mathrm{mM}, \mathrm{pH} 7.4)$, $\mathrm{MnCl}_{2}(2 \mathrm{mM})\left[\gamma^{\left.-{ }^{32} \mathrm{P}\right] \mathrm{ATP}}(10 \mu \mathrm{m} ; 5000 \mathrm{cpm} / \mathrm{pmol} ;\right.$ 
NEN), BSA $(0.125 \mathrm{mg} / \mathrm{ml}), \mathrm{Na}_{3} \mathrm{VO}_{4}(50 \mu M)$, and PNPP ( $p$-nitrophenyl phosphate; $10 \mathrm{mM}$ ) in a total volume of $60 \mu \mathrm{l}$. After $10 \mathrm{~min}$ at $0^{\circ} \mathrm{C}$, the reaction was stopped by addition of SDS-sample buffer and raising the temperature to $100^{\circ} \mathrm{C}$ for $5 \mathrm{~min}$. Samples were then subjected to SDS-gel electrophoresis and autoradiography.

(ii) Exogenous phosphorylation of synthetic, tyrosinecontaining peptides. Membranes were prepared as above and preincubated with EGF for $10 \mathrm{~min}$ at $30^{\circ} \mathrm{C}$. The phosphorylation reaction was started by adding membranes to a reaction mixture similar to that above, without BSA but containing Nonidet P40 $(0.2 \%)$ and one of three peptide substrates $(2 \mathrm{~m} M$; final volume 30 $\mu \mathrm{l}$; Pike et al., 1982; Wong and Goldberg, 1983). After 3 - to $4 \mathrm{~min}$ incubation at $30^{\circ} \mathrm{C}$, the reaction was stopped by adding TCA (50 $\mu \mathrm{l}$ of $5 \% \mathrm{v} / \mathrm{v})$ and BSA (20 $\mu \mathrm{l}$ of $25 \mathrm{mg} / \mathrm{ml}$ ). Samples were then centrifuged for 4 min at $10,000 g$, the supernatant was "spotted" on filters (Whatman P81 phosphocellulose paper), and washed six times in phosphoric acid ( $75 \mathrm{mM}$ ). After drying, radioactivity on the filters was determined by liquid scintillation counting. A correction for aspecific phosphorylation was made by ommitting peptide from the assay mixture.

(iii) High-voltage electrophoresis. The stained protein bands required were excised from the gel (i, above), allowed to swell in $\mathrm{NH}_{4} \mathrm{HCO}_{3}(100 \mathrm{mM})$, and incubated in trypsin $(100 \mu \mathrm{g} / \mathrm{ml})$ for $24 \mathrm{hr}$ at $37^{\circ} \mathrm{C}$ on a shaker to elute labeled proteins. The elutant was centrifuged and the supernatant dialyzed at $4^{\circ} \mathrm{C}$ against $\mathrm{H}_{2} \mathrm{O}$ then dried under reduced pressure in a Speed Vac concentrator. The dry sample was hydrolyzed in $0.4 \mathrm{ml} \mathrm{HCl}$ $(6 \mathrm{~N})$ for $2 \mathrm{hr}$ at $110^{\circ} \mathrm{C}$ under vacuum. $\mathrm{HCl}$ was then removed under reduced pressure, the hydrolysates were resuspended in $10 \mu \mathrm{l} \mathrm{H}_{2} \mathrm{O}$ containing $10 \mu \mathrm{g}$ each of marker phosphoserine, phosphothreonine, and phosphotyrosine and analyzed by one-dimensional, highvoltage paper electrophoresis at $\mathrm{pH} 3.5(1500 \mathrm{~V}, 1.5 \mathrm{hr})$ in $5 \%$ glacial acetic acid, $0.005 M$ EDTA. The markers were visualized by ninhydrin staining and radioactive material localized autoradiographically.

\section{RESULTS}

\section{Isolation of Differentiated Lines}

In the presence of RA, aggregates of P19 cells differentiate to a number of cell types including neuronal and glial tissue but no muscle whereas in the presence of DMSO cardiac and skeletal muscle tissue may form but not neurons (Jones-Villeneueve et al., 1982). We treated aggregates of P19 cells with RA for 3 days, then allowed them to develop for 2 weeks on an adhesive substrate; the cultures then consisted of a heterogeneous mixture of cell types. These cells were subsequently cloned by limiting dilution in 96 -well plates. After 3 weeks, $65 \%$ (13) of the maximum number of wells theoretically possible contained colonies of cells with predominantly endodermal- or epitheliallike morphologies. All of the clones could be serially passaged over extended periods (minimally 4 months) without the reappearance of stem cell colonies or gross changes in morphology. This contrasts with other EC lines where differentiated cell populations often contain
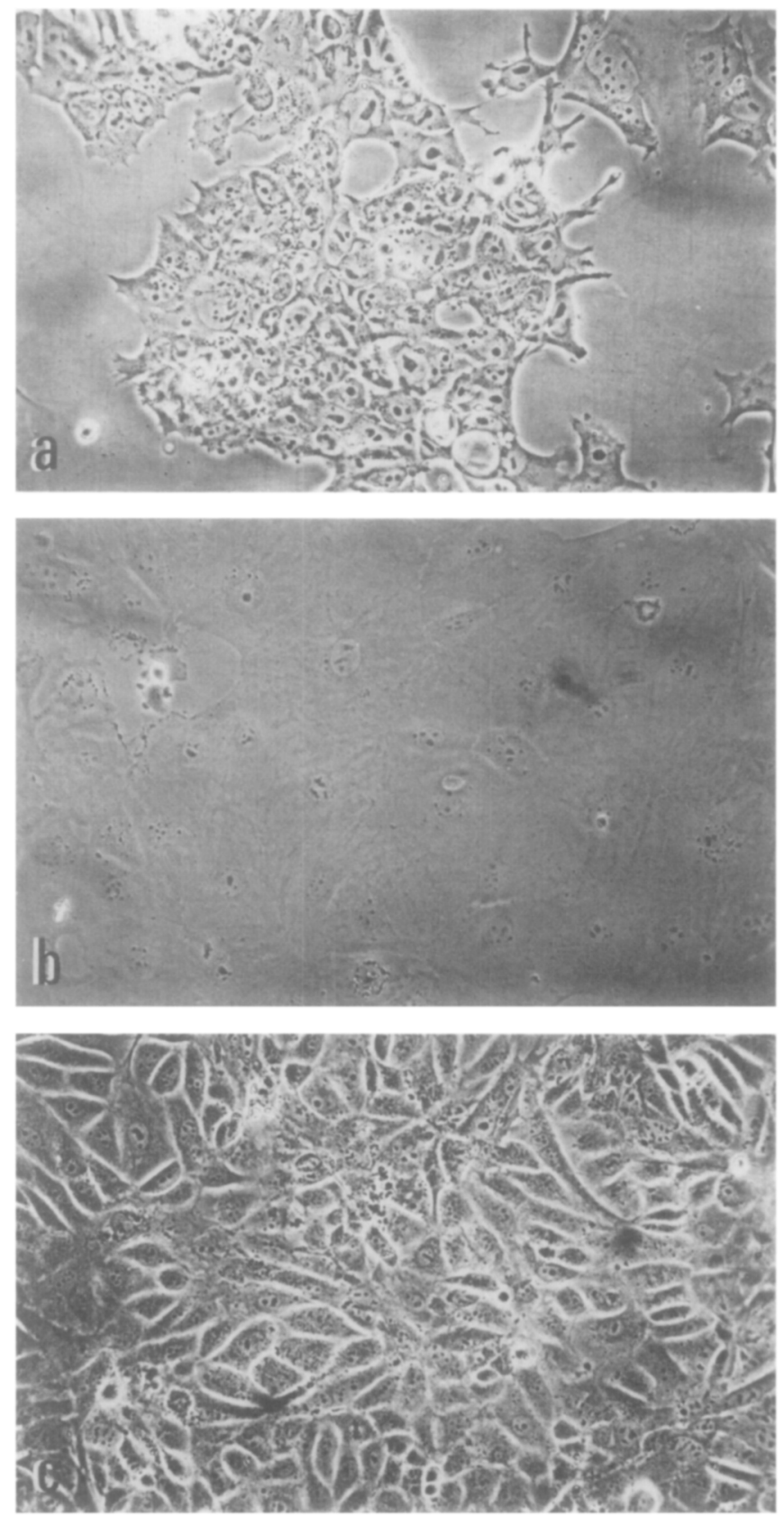

FIG. 1. Morphology of P19 EC cells (a) (large nuclear: cytoplasm ratio, growth in "islands") compared with differentiated P19 derivatives END-2 (b) (flat endodermal, no overgrowth when confluent, little cytoplasmic contrast) and EPI-7 (c) (epithelioid, refractile, overgrowth at confluence). 
'I'ABLE' 1

Comparison of Blochemical Markers and Growth Properties of P19 EC, END-2 and EPI-7 Celis

\begin{tabular}{|c|c|c|c|}
\hline \multirow[b]{2}{*}{ Characteristic } & \multicolumn{3}{|c|}{ Cell type } \\
\hline & $\mathrm{EC}$ & END-2 & EPI-7 \\
\hline Morphology & $\begin{array}{l}\text { Large nucleus: } \\
\text { cytoplasm ratio }\end{array}$ & Flat, endodermal & Epithelioid \\
\hline \multicolumn{4}{|l|}{ (A) Marker expression } \\
\hline Plasminogen activator (Plough units $/ 10^{6}$ cells $/ 24 \mathrm{hr}$ ) & $0.05 \pm 0.01$ & $1.88 \pm 0.18$ & $0.07 \pm 0.01$ \\
\hline Alkaline phosphatase $(\Delta E / \mathrm{min} / \mu \mathrm{g}$ protein $)$ & $3.25 \times 10^{-4}$ & $1.35 \times 10^{-4}$ & $0.69 \times 10^{-4}$ \\
\hline Fibronectin & - & + & + \\
\hline Laminin & - & + & + \\
\hline SSEA-1 & + & - & - \\
\hline$\alpha$-Fetoprotein & - & - & - \\
\hline \multicolumn{4}{|l|}{ (B) Growth properties } \\
\hline Generation time ${ }^{a}(\mathrm{hr})$ & $14.3 \pm 1.0$ & $25.0 \pm 3.0$ & $19.3 \pm 2.9$ \\
\hline Soft agar growth (\% colonies) & $29.0 \pm 2.0$ & $<2$ & $<2$ \\
\hline Growth factor requirement & - & + & - \\
\hline EGF binding ${ }^{b}$ (receptors/cell) & 900 & $60,000-78,000$ & $39,000-42,000$ \\
\hline \multicolumn{4}{|l|}{ Mitogenic response to } \\
\hline EGF & - & + & + \\
\hline Insulin & $\mathrm{ND}$ & + & - \\
\hline PDGF & ND & & - \\
\hline
\end{tabular}

${ }^{a}$ Cell counting after trypsinization.

${ }^{s}$ Range in three separate experiments.

residual stem cells (e.g., Isacke and Deller, 1983) and have a limited capacity for division in culture.

\section{Characterization of Differentiated Lines}

We selected two lines for detailed study on the basis of differences in their morphology and in growth rates.
The morphologies of P19 EC cells and the differentiated lines are shown in Figs. 1a-c, respectively. END-2 cells were typically extremely flattened with an endodermlike morphology while EPI-7 were more epithelioid and refractile.

(1) Marker expression. 'lable 1A summarizes the expression of various biochemical markers in these

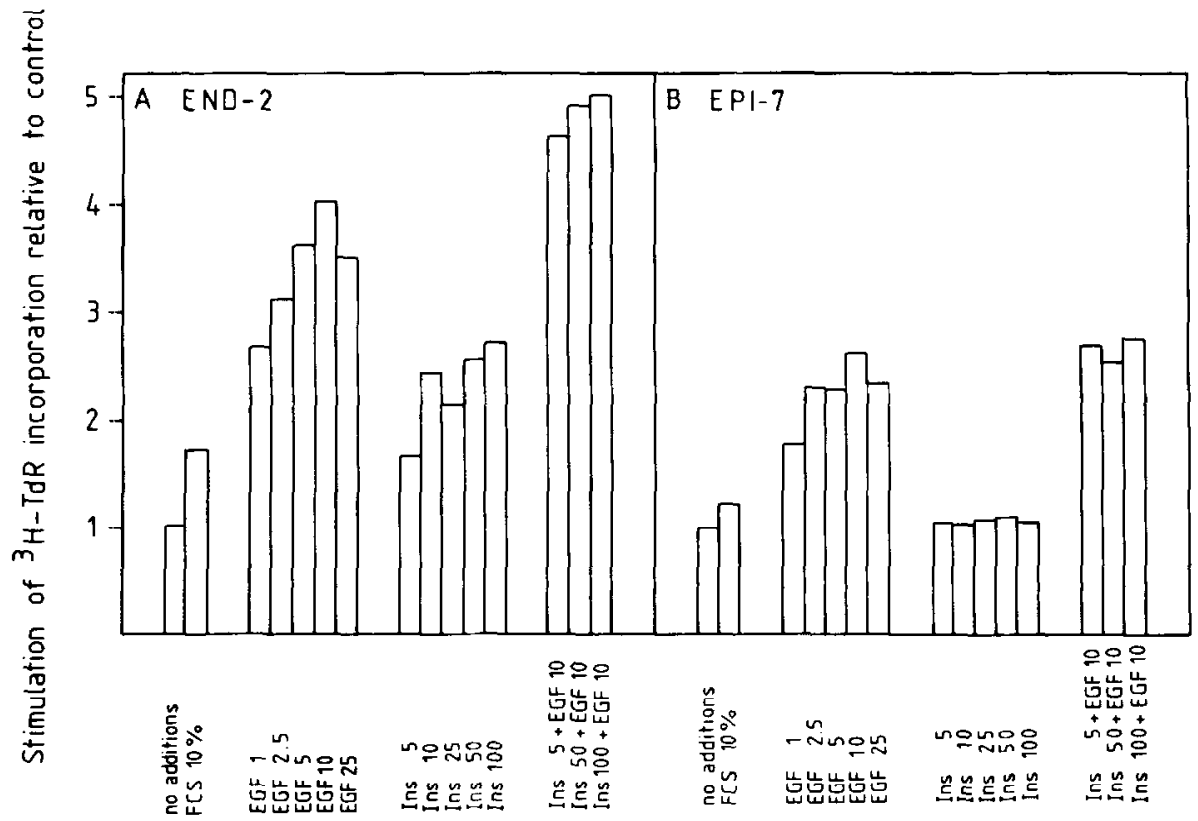

FIG. 2. Effect of growth factors on $\left[{ }^{3} \mathrm{H}\right] \mathrm{TdR}$ incorporation in (A) END-2 and (B) EPI-7. Confluent cultures were preincubated in $\mathrm{DF}+0.5 \% \mathrm{FCS}$ for $72 \mathrm{hr}$ before growth factor addition for $24 \mathrm{hr}$ with $\left[{ }^{3} \mathrm{H}\right] \mathrm{TdR}$ present for the last $16 \mathrm{hr}$, as described under Materials and Methods. Data has been normalized to control values. For END-2 basal levels of $\left[{ }^{2} \mathrm{H}\right] \mathrm{TdR}$ incorporation during the experiment were $\sim 16,000$ dpm $/ 10^{5}$ cells and for EPI-7 $\sim 200,000 \mathrm{dpm} / 10^{5}$ cells. In all cases increases in cell number paralleled increases in [ $\left.{ }^{3} \mathrm{H}\right] \mathrm{TdR}$ incorporation (not shown). Concentrations given are in nanograms per milliliter. 
two lines compared with stem cells. END-2 and EPI-7 have a number of features in common which distinguish them from stem cells; extracellular matrix proteins fibronectin and laminin are detectable by indirect immunofluorescence, there is no expression of the SSEA-1 determinants found on EC cells, and levels of alkaline phosphatase activity are lower. T'he clones are, however, not identical with respect to all markers; plasminogen activator production, a diagnostic marker used to characterize endoderm cell populations (Strickland and Mahdavi, 1978) is, for example, barely detectable in EPI-7 and undifferentiated EC cells whereas large amounts are synthesized by END-2 cells.

(2) Growth properties. The doubling time of P19 EC cells is comparable with that in other EC lines (Mummery et al., 1984) whereas that of EPI-7 and END-2 is about twice as long (Table $1 \mathrm{~B}$ ). EGF is mitogenic for both lines. Maximum (three- to fourfold) stimulation of cummulative $\left[{ }^{3} \mathrm{H}\right]$ thymidine $\left({ }^{3} \mathrm{H}-\mathrm{TdR}\right)$ incorporation is induced in both cases by $10 \mathrm{ng} / \mathrm{ml}$ (Figs. 2A,B);

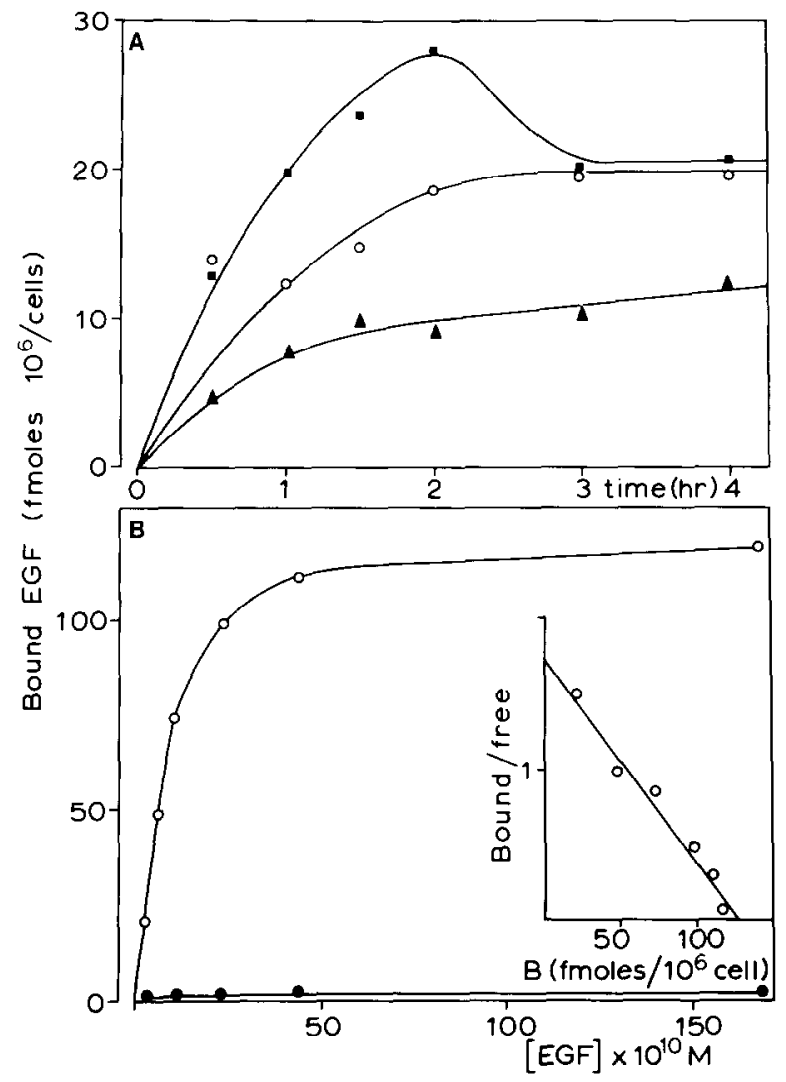

FIG. 3. EGF binding characteristics of END-2. (A) Time course of specific ${ }^{125} \mathrm{I}$-EGF binding $(1 \mathrm{ng} / \mathrm{ml})$ at $37(\boldsymbol{\bullet}), 20(\mathrm{O})$, and $4^{\circ} \mathrm{C}(\Delta)$, determined as described under Materials and Methods. (B) EGF binding as a function of external EGF concentration after 2-hr incubation at $20^{\circ} \mathrm{C}$ in END-2 (O) compared with P19 EC cells (๑). Insert shows Scatchard analysis of EGF binding to END-2 (B $=$ specifically bound). Data shown is from one of three experiments giving similar results. Comparable EGF binding was found in EPI7 cells (not shown).

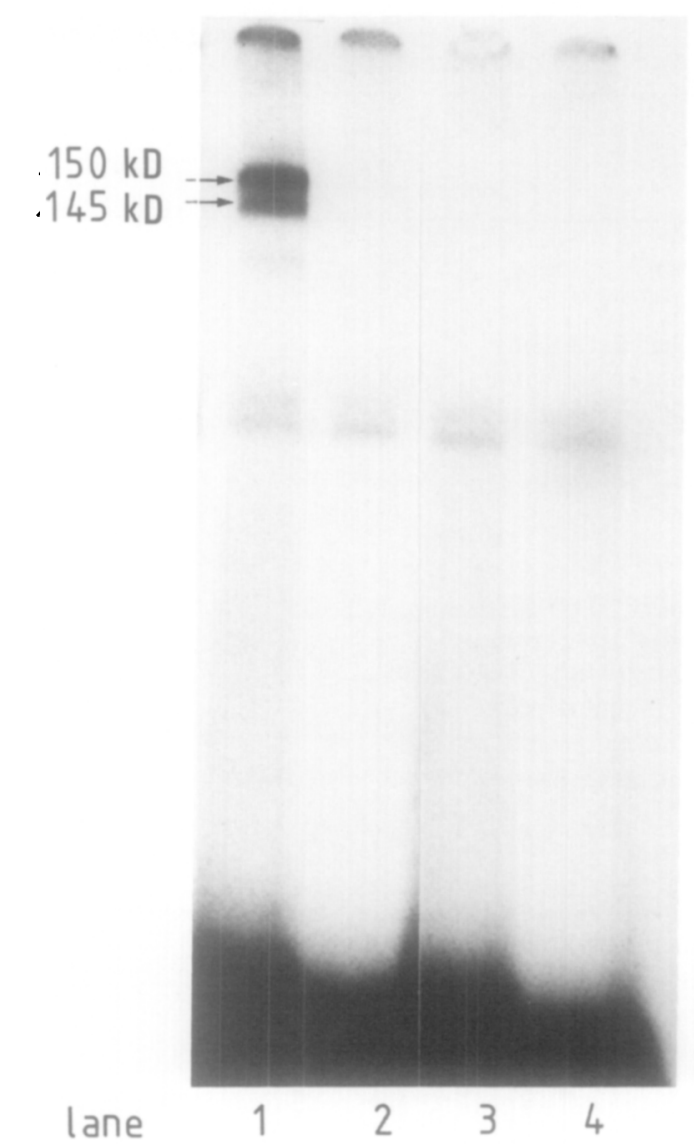

FIG. 4. ${ }^{125}$ I-EGF binding to isolated plasma membranes from END2 (lane 1; lane 2 with excess, unlabeled EGF) and from P19 EC cells (lane 3; lane 4 with excess, unlabeled EGF). Bound ${ }^{125}$ I-EGF was crosslinked to its receptors using DSIS prior to SDS-gel electrophoresis, as described under Materials and Methods. The lighter bands at $67 \mathrm{kDa}$ represents aspecifically bound bovine serum albumin present during the assay.

however, ${ }^{3} \mathrm{H}$-TdR incorporation is stimulated only in END-2 by nanogram per milliliter concentrations of insulin (maximum two- to threefold; Fig. 2A). The increases in DNA synthesis are followed by increases in cell number at cell densities below confluence. Neither line responds to PDGF (Table 1B). Whereas END-2 becomes quiescent under the conditions of high cell density and low serum concentration used in these growth experiments, EPI-7 continues to proliferate, albeit at a reduced rate (doubling time $30.0-35.0 \mathrm{hr}$ ), and retains a high basal level of ${ }^{3} \mathrm{H}-\mathrm{TdR}$ incorporation (legend Fig. 2). Indeed EPI-7 could be passaged in the complete absence of externally added hormones or growth factors (Table 1B) and medium conditioned for $24 \mathrm{hr}$ by near-confluent cultures of EPI-7 could stimulate ${ }^{3} \mathrm{H}-\mathrm{TdR}$ incorporation into END-2 cells (to be published elsewhere). Neither END-2 nor EPI-7 were able to grow in soft agar, in contrast to P19 EC cells (Table 1B). The ability to grow in semisolid media in vitro has been highly correlated with the ability to form tumors in vivo. Neither line had therefore retained 
tumorigenic potential during differentiation. Since both lines could be serially passaged, sufficient cell numbers $\left(2 \times 10^{8}\right.$ cells) were easily generated for preparation of plasma membranes. We took advantage of this property to characterize in detail for the first time the response of $\mathrm{EGF}$ receptors in the progeny of an EC cell line to $\mathrm{EGH}$.

\section{EGF Binding}

Both lines showed EGF specific binding, internalization at $37^{\circ} \mathrm{C}$ (Fig. $3 \mathrm{~A}$ ), and saturation binding kinetics (Fig. 3B). Scatchard analysis of binding data (Fig. 3B, inset) indicated that END-2 cells have $6.0-7.8 \times 10^{4}$ EGF receptors/cell with an dissociation constant, $K_{\mathrm{d}}$, of $0.76-1.64 \times 10^{-9} M$ (range in three experiments), comparable with values in PC13 END cells (Rees et al., 1979). EPI-7 have slightly fewer receptors per cell (Table 1) with similar affinities but given the apparent size difference the receptor densities per cell may be similar. Specific EGF binding was barely detectable on the stem cell population (Fig. $3 \mathrm{~B} ; 8.9 \times 10^{2}$ receptors/ cell, $K_{\mathrm{d}}=0.47 \times 10^{-9} M$ ) and may be due to low levels of spontaneous differentiation. Membranes isolated ac-

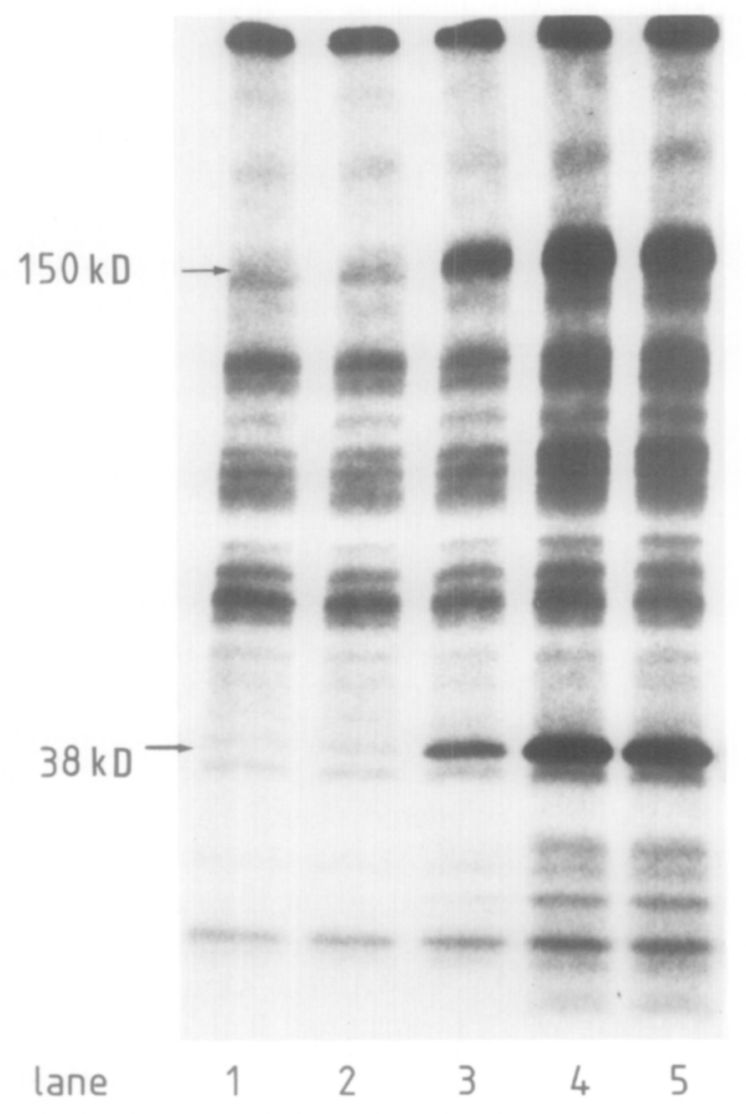

FIG. 5. Endogenous phosphorylation of END-2 membrane proteins by EGF. Lanes 1-6 show effects of increasing concentrations of EGF, i.e., land 1: control, lanes 2-5: $1.67,16.7 \mathrm{ng} / \mathrm{ml}, 0.167$, and $1.67 \mu \mathrm{g} /$ $\mathrm{ml}$, respectively. Isolation of membranes and assay, as described under Materials and Methods. Similar results were obtained using EPI-7. cording to Thom et al. (1977) still contained receptors which bound EGF specifically, as shown in Fig. 4 for END-2 (lanes 1 and 2). In this case ${ }^{125} \mathrm{I}-\mathrm{EGF}$ bound to membranes in the absence and presence of excess, unlabeled EGF was crosslinked to the receptor prior to SDS-gel electrophoresis. Bands representing the $\mathrm{EGF}$ receptor appear as a doublet at $150 \mathrm{kDa}$, as has been found in other cell types previously (King et al., 1980). Membranes isolated from EC cells were still unable to bind EGF (Fig. 4, lanes 3 and 4) under these conditions so it appeared unlikely that unoccupied receptors were available at the cell surface.

\section{EGF-Induced Phosphorylation}

Preincubation of membranes isolated from END-2 cells with EGF followed by $\left[\gamma^{32} \mathrm{P}\right] \mathrm{ATP}$ and divalent cations induced distinctive changes in phosphorylation or both endogenous and exogenous substrates. Autoradiograms of samples subjected to SDS-PAGE showed that various concentrations of EGF resulted in the appearance of ${ }^{32} \mathrm{P}$-labeled bands at 150 and $38 \mathrm{kDa}$ (Fig. 5, lanes 1-5), as observed in other cells (Hunter and Cooper, 1981; Cooper and Hunter, 1981). The 34to $39-\mathrm{kDa}$ proteins are thought to be associated with detergent-insoluble cytoskeletal structures (Cheng and Chen, 1981; Cooper and Hunter, 1982; Nigg et al., 1983). Comparable results were found in EPI- 7 but EGF induced no changes in phosphorylation in membranes from EC cells (not shown). Indirect and direct evidence showed that EGF induced phosphorylation was tyrosine specific. First, preincubation of membranes from the differentiated P19 clones with EGF then $\left[\gamma^{32} \mathrm{P}\right]$ ATP and a synthetic peptide containing only tyrosine residues but no scrine or threonine (angiotensin I and II or RRsrc; Pike et al., 1982; Rosen et al., 1983) induced a two- to fourfold stimulated ${ }^{32} \mathrm{P}$ incorporation into the peptide (Fig. $6 \mathrm{~B}$ ); the stimulation factor depended on the peptide used and may reflect the relative efficiency with which each is phosphorylated. The EGF dose dependence for phosphorylation of angiotensin I is shown in Fig. 6C. The specificity of the stimulation for EGF/EGF receptor is again illustrated by comparing the results with those obtained under the same conditions in EC cells (Fig. 6A). Unexpectedly, basal levels of phosphorylation of all three peptides were higher in differentiated than in EC cells. This contrasts with results of Stern and Heath (1983) in PC13 EC cells where phosphotyrosine levels were reduced after differentiation. The differentiated derivatives of P19 and PC13 may, however, represent different cell types and the results therefore not be directly comparable. Second, high-voltage electrophoresis of the 150- and $38-\mathrm{kDa}$ bands confirmed the tyrosine specificity of EGF-induced phosphorylation (Fig. 7). EGF had no effect on serine or threonine residues in either band. 


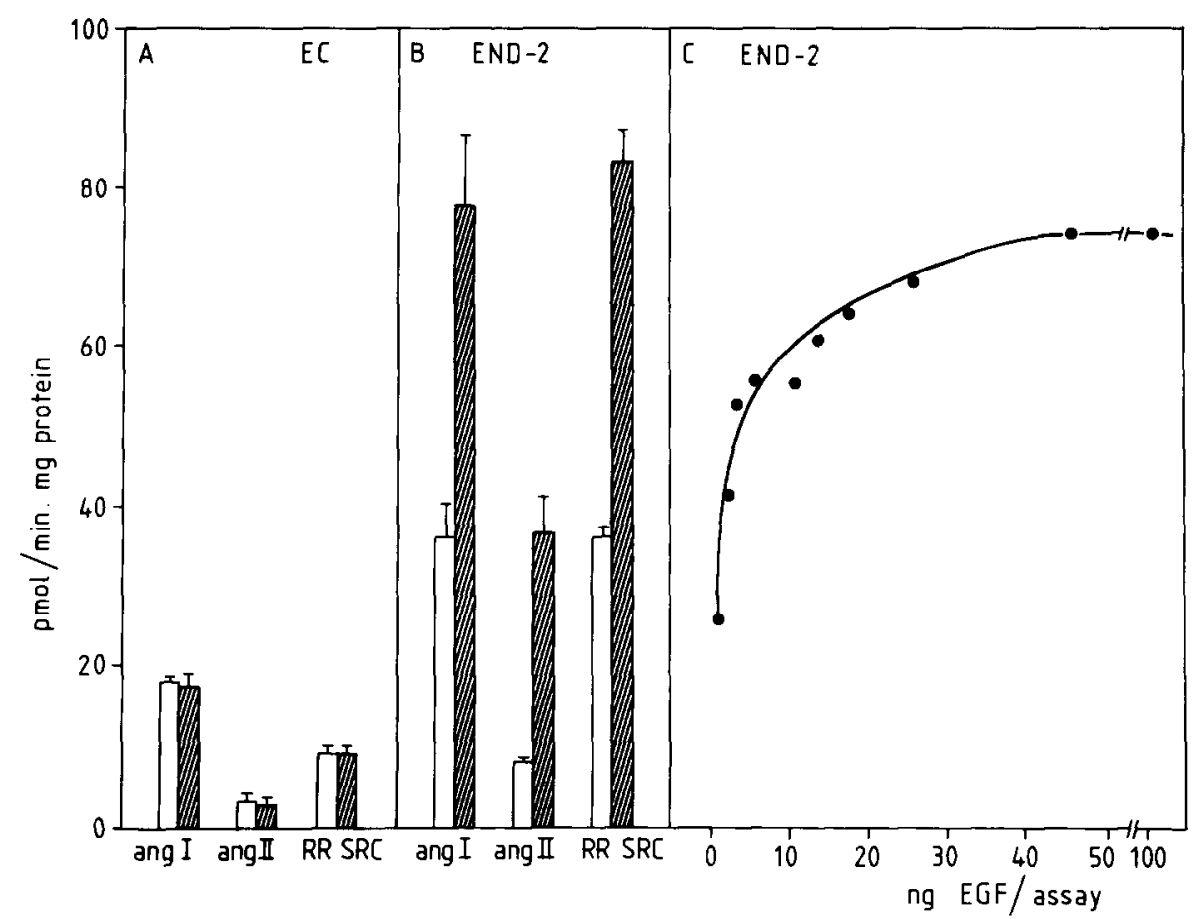

Frg. 6. Phosphorylation of exngenous substrates by isolated membranes. (A) P19 EC cells, (B) END-2. Membranes were preincubated with EGF for $10 \mathrm{~min}$ at $30^{\circ} \mathrm{C}$ and phosphorylation started by adding them to a reaction mixture with one of the three peptides angiotensin I (ang I), angiotensin II (ang II) or RRsrc, containing tyrosine residues only, as described under Materials and Methods. Hatched bars indicate the presence of EGF. (C) EGF dose-response curve with END-2 using angiotensin I. Comparable results were obtained using membranes from EPI-7 (not shown).

\section{DISCUSSION}

We have isolated several differentiated clones from a pluripotent EC cell, P19 and characterized two in particular for their response to growth factors. One of these clones (END-2) resembled the END cells derived by RA treatment of the nullipotent $\mathrm{EC}$ line, PC13 (Rees et al., 1979; Mummery et al., 1984) not only morphologically but in the expression of differentiationspecific markers and growth properties. The other (EPI-7) resembled a cell line (dif. 5) derived by prolonged treatment of F9 cells with RA (Nagarajan et al., 1983) again not only morphologically but also in the expression of EGF binding sites and extracellular matrix proteins. $\Lambda \mathrm{s}$ F9-dif. 5, EPI-7 can proliferate in the absence of added mitogenic factors, suggesting that these cells produce factor(s) able to promote growth in an autocrine manner. Given the differential response of the two clones to insulin, an attractive candidate for a factor produced by EPI-7 is an insulinlike growth factor. The possibility of endogenous growth factor production by EPI-7 does, however, complicate interpretation of growth stimulation studies with these cells. It cannot be excluded that such factors may act synergistically with exogenous factors under the conditions of the assay. In contrast to F9-dif. 5, EPI-7 produces very little plasminogen activator nor does it become quiescent at confluency. Neither END-2 nor EPI-7 respond mitogenically to PDGF, suggesting that neither resemble mesodermal derivatives.
Several lines of EC cells induced to differentiate by RA develop receptors for epidermal growth factor (EGF), become subject to exogenous growth control (Rees et al., 1979; Rizzino et al., 1983), and have reduced ability to form tumors (Rayner and Graham, 1982). Although END-2 cell exhibited all of these properties, EPI-7 cells remained largely insensitive to exogenous growth control except with respect to EGF. This might suggest that expression of these properties is temporally uncoupled during differentiation or, alternativcly, that their differential expression may play a role in determining the differentiated cell type. Recent studies have shown that the EGF receptor in a variety of epithelial and epidermal cells contains a protein kinase which is rapidly and specifically phosphorylated on tyrosine following EGF binding (Ushiro and Cohen, 1980). It might be expected therefore, that the EGF receptor, if present in EC derivatives would also be phosphorylated on tyrosine, although to date the formal proof has been lacking. The present study provides this proof. The results show that several plasma membrane proteins of differentiated P19 cells are phosphorylated endogenously by EGF; these proteins include a $150-\mathrm{kDa}$ doublet (the EGF receptor) and a $38-\mathrm{kDa}$ protein. After preincubation with EGF these membranes were able to catalyze phosphorylation of exogenous peptide substrates containing tyrosine residues. The reason for the higher background levels of tyrosine phosphorylation of the differentiated cell membranes 


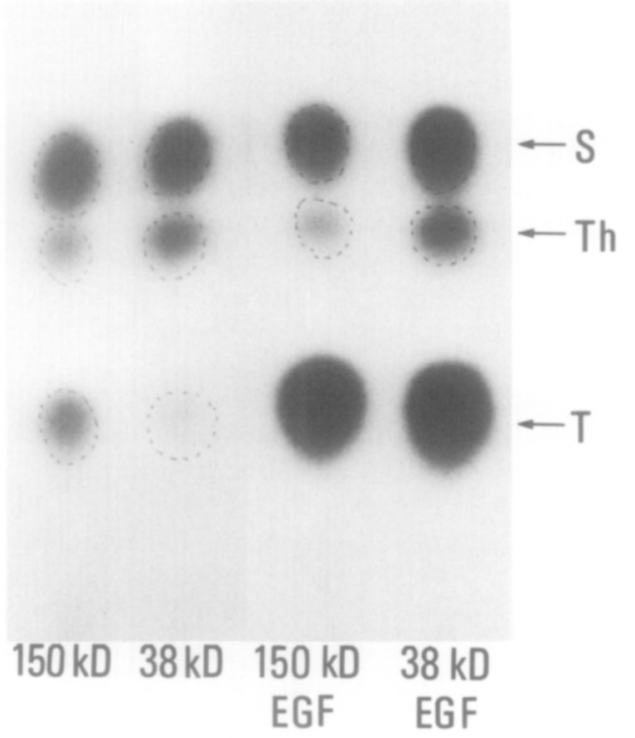

FiG. 7. Tyrosine specificity of EGF phosphorylation. Bands of 150 and $38 \mathrm{kDa}$ indicated in Fig. 5 were cut from SDS-gels and subjected to high-voltage electrophoresis as described under Materials and Methods. Lanes 1 and 2 (150 and $38 \mathrm{kDa}$, respectively) show bands from membranes not treated with EGF, where there is little phosphorylation on tyrosine ( $\mathrm{T}$ ), and lanes 3 and 4 , the same bands from membranes treated with $1.67 \mu \mathrm{g} / \mathrm{ml}$ EGF (i.e., lane 5 in Fig. 5). Phosphorylation on serine (S) and threonine (Th) is unchanged by EGF treatment while significantly increased on tyrosine residues.

compared with those from EC cells on these peptides is unclear although patterns of protein phosphorylation, including that on tyrosine residues, are known to be developmentally regulated (Carlin et al, 1983; Dasgupta and Garbers, 1983). The formation of endoderm is among the first differentiation events in the developing mouse embryo, occurring shortly after implantation around Day 5 of gestation (Enders et al., 1978; Gardner, 1981). The earliest stage of development in mouse embryos a.t which functional EGF receptor kinase has been detected is around the time of onset of organogenesis at Days 9 and 10 of gestation, some 4 days after implantation (Hortsch et al., 1984). It has been suggested that the failure to detect FGF receptor kinase activity in late preimplantation and early postimplantation embryos may be due to either levels of activity below the sensitivity of the assay or to EGF receptors present having no integral kinase activity (Hortsch et al., 1984). If the cell lines described above are representative of those in early development, the present results would argue in favor of the former rather than the latter possibility. In conclusion, the differentiated clones described in this study represent populations of cells each expressing a particular subset of genetic information present in a common ancestral genome. As such they may therefore prove invaluable for studying the developmental regulation of gene expression, particularly the differential expression of receptors for and response to growth factors.
We thank M. W. McBurney for permission to use and C. F. Graham for providing the P19 cell line and E. J. J. van Zoelen for critical reading of the manuscript. This investigation was supported by Shell Internationale Research Maatschappij and the Netherlands Ministry of Housing, Physical Planning and the Environment.

\section{REFERENCES}

Artzt, K., Dubois, P., Bennet, D., Condamine, H., Babinet, C., and JACOB, F. (1973). Surfare antigens common to mouse cleavage embryos and primitive teratocarcinoma cells in culture. Proc. Natl. Acad. Sci. USA 70, 2988-2992.

Bernstine, E. G., Hooper, M. L., Grandchamp, S., and Ephrussi, B. (1973). Alkaline phosphatase activity in mouse teratoma. Proc Natl. Acad. Sci. USA 70, 3899-3902.

CARLIN, C. R., and KNowles, B. B. (1982). Identity of human epidermal growth factor (EGF) receptor with glycoprotein SA7: Evidence for differential phosphorylation of the two components of the EGF receptor from A431 cells. Proc. Natl. Acad. Sci. USA 79, 5026-5030.

Carlin, C. R., McGrath, J., Searls, D. B., Solter, D., and Knowles, B. (1983). Phosphoproteins of early mouse embryos and teratocarcinoma-derived cell lines. In "Teratocarcinoma Stem Cells" (L. M Silver, G. R. Martin, and S. Strickland, eds.), Vol. 10, pp. 245-255. Cold Srping Harbor.

Cheng, Y.-S., and ChEN, L. B. (1981). Detection of phosphotyrosine containing 36,000 dalton protein in the frame work of cells transformed with Rous carcinoma virus. Proc. Natl. Acad. Sci. USA 78, $2388-2392$

COOPER, J. A., and HUNTER, T. (1981). Similarities and differences between the effects of epidermal growth factor and Rous carcinoma virus. J. Cell Biol. 91, 878-883.

COOPER, J. A., and HUNTER, T. (1982). Discrete primary locations of a tyrosine protein kinase and of three proteins that contain phosphotyrosine in virally transformed chick fibroblasts. $J$. Cell Biol. 94, 287-296.

Dasgupta, J. E., and Garbers, D. L. (1983). Tyrosine protein kinase activity during embryogenesis. J. Biol. Chem. 258, 6174-6178.

ENDERs, A. C., Given, R. L., and SchlafKe, S. (1978). Differentiation and migration of endoderm in the rat and mouse at implantation. Anat. Res. 190, 65-78.

GakDNEK, R. L. (1981). In vivo and in vitro studies on cell lineage and determination in the early mouse embryo. In "Cellular Controls in Differentiation" (C. W. Lloyd and D. A. Rees, eds.), pp. 257-278 Academic Press, New York

GRAHAM, C. F. (1977). Teratocarcinoma stem cells and normal mouse embryogenesis. In "Concepts in Mammalian Embryogenesis" (M. I. Sherman and C. F. Graham, eds.), pp. 315-394. MIT Press, Cambridge, Mass.

Heath, J. K., Bell, S. M., and ReEs, A. R. (1981). The appearance of functional insulin receptors during the differentiation of embryonal carcinoma cells. J. Cell Biol. 91, 293-297.

Hortsch, M., Schlessinger, J., Gootwine, E., and Webb, C. G. (1984). Appearance of functional EGF receptor kinase during rodent embryogenesis. EMBO J. 2, 1937-1941.

Hunter, T., and COOPER, J. A. (1981). Epidermal growth factor induces rapid tyrosine phosphorylation of proteins in A431 human tumour cells. Cell 24, 741-752

ISACKE, C. M., and Dellek, M. J. (1983). Teratocarcinoma cells exhibit growth cooperativity in vitro. J. Cell. Physiol. 117, 407-414.

Jetten, A. M., Jetten, M. E. R., Shapiro, S., and Poon, J. (1979). Characterization of the action of retinoids on mouse fibroblast cell lines. Exp. Cell. Res. 119, 289-299.

Jones-Villeneuve, E. M., McBurney, M. W., Rogers, K. A., and KaLNINS, V. I. (1982). Retinoic acid induces embryonal carcinoma cells to differentiate into neurons and glial cells. $J$. Cell Riol. 94, 253-262. 
KING, L. E., Carpenter, G., and CoHEN, S. (1980). Characterization by electrophoresis of epidermal growth factor stimulated phosphorylation using A431 membranes. Biochemistry 19, 1524-1528.

Lehman, J. M., Speers, W. C., Swartzendruber, D. E., and Pierce, G. B. (1974). Neoplastic differentiation: Characteristics of cell lines derived from a murine teratocarcinoma. J. Cell. Physiol. 84, 13-28.

Martin, G. R. (1980). Teratocarcinomas and mammalian embryogenesis. Science (Washington, D. C.) 209, 768-775.

Martin, G. R., and Evans, M. J. (1975). Differentiation of clonal lines of teratocarcinoma cells: Formation of embryoid bodies in vitro. Proc. Natl. Acad. Sci. USA 72, 1441.

McBurney, M. W., and Rogers, B. J. (1982a). Isolation of male embryonal carcinoma cells and their chromosome replication patterns. Dev. Biol. 89, 503-508.

McBurney, M. W., Jones-Villeneuve, E. M., Edwards, M. K. S., and ANDERson, P. J. (1982b). Control of muscle and neuronal differentiation on a cultured embryonal carcinoma cell line. Nature (London) 299, 165-167.

Morgan, R. H. M., Henry, J. A., and Hooper, M. C. (1983). Isolation of cell lines from differentiating embryonal carcinoma cultures. Exp. Cell Res. 148, 461-473.

Mummery, C. L., van den Brink, C. E., van der SaAg, P. T., and DE LAAT, S. W. (1984). The cell cycle, cell death and cell morphology during retinoic acid induced differentiation of embryonal carcinoma cells. Dev. Biol. 104, 297-307.

Mummery, C. L., van der SaAG, P. T., and de LAat, S. W. (1983). Loss of EGF binding and cation transport response during differentiation of neuroblastoma cells. J. Cell Biochem. 21, 63-75.

Nagarajan, L., JetTen, A. M., and Anderson, W. B. (1983). A new differentiated line (Dif. 5) derived by retinoic acid treatment of F9 teratocarcinoma cells capable of extracellular matrix production and growth in the absence of serum. Exp. Cell Res. 147, 315-327.

Nicolas, J. F., Avner, P., Gaillard, J., Guenet, J.-L., Jakob, H., and $J_{A C O B}, F .(1976)$. Cell lines derived from teratocarcinomas. Cancer Kes. 36, 4224.

Nigg, E. A., Cooper, J. A., and Hunter, T. (1983). Immunofluorescent localization of a 39,000 dalton substrate of tyrosine protein kinases to the cytoplasmic surface of the plasma membrane. J. Cell Biol. 96, 1601-1609.

Pike, L. J., Gallis, B., Casnellie, J. E., Bornstein, P., and Krebs, E. G. (1982). Epidermal growth factor stimulates the phosphorylation of synthetic tyrosine-containing peptides by $\Lambda 431$ cell membranes. Proc. Natl. Acad. Sci. USA 79, 1443-1447.

PILCH, P. R., and CzECH, M. P. (1979). Interaction of cross-linking agents with the insulin effector system of isolated fat cells. $J$. Biol. Chem. 254, 3375-3381.

RAYNER, M. J., and GRAHAM, C. F. (1982). Clonal analysis of the change in growth phenotype during embryonal carcinoma cell differentiation. J. Cell Sci. 58, 331-344.

REEs, A. R., ADAMSON, E. D., and GRAHAM, C. F. (1979). Epidermal growth factor receptors increase during the differentiation of embryonal carcinoma cells. Nature (London) 281, 309-311.

RHEINWALD, J., AND GREEN, H. (1975). Formation of keratinizing epithelium in culture by a cloned cell line derived from a teratoma Cell 6, 317-330.

Rizzino, A., Orme, L. S., and DE Larco, J. E. (1983). Embryonal carcinoma cell growth and differentiation. Production of the response to molecules with transforming growth factor activity. Exp. Cell Res. 143, 143-152.

Rosen, O. M., Herrer, A. R., Olowe, Y., Petruzzelli, L. M., and Совв, M. H. (1983). Phosphorylation activates the insulin receptor tyrosine protein kinase. Proc. Natl. Acad. Sci. USA 80, 3237-3240.

SCATCHARD, G. (1949). The attraction of proteins for small molecules and ions. Ann. N. Y Acad Sci. 51, 660-672.

Stern, P. L., and Heath, J. K. (1983). Growth control of teratocarcinomas. In "Development of Mammals" (M. J. Johnson, ed.), Vol $\mathrm{V}$, pp. 107-133.

Strickland, S., and Mahdavi, V. (1978). The induction of differentiation in teratocarcinoma stem cells by retinoic acid. Cell $15,393-$ 403 .

Thom, D., Powell, A. J., Lloyd, C. W., and Rees, D. A. (1977). Rapid isolation of plasma membranes in high yield from cultured fibroblasts. Biochem. J. 168, 187-194.

Todaro, G. J., De Larco, J. E., Fryling, C., Johnson, P. A., and SPORN, M. B. (1981). Transforming growth factors (TGFs): Properties and possible mechanisms of action. J. Supramol. Struct. Cell Biochem. 15, 287-301

Unkeless, J. C., ToBiA, A., Ossowski, K. L., Quigley, J. P., Rifkin, D. B., and REICH, E. (1973). An enzyme associated with transformation of fibroblasts by oncogenic viruses. Eur. J. Exp. Med. 137, 85.

Ushiro, H., and CoHEN, S. (1980). Identification of phosphotyrosine as a product of epidermal growth factor-activated protein kinase in A431 cell membranes. $J$. Biol. Chem. 255, 8363.

WONG, T. W., and GoLDBERG, A. R. (1983). In vitro phosphorylation of angiotensin analogs by tyrosyl protein kinases. J. Biol. Chem. 258, 1022-1025. 